\title{
WATER PRODUCTION FUNCTION AND MATHEMATICAL OPTIMIZATION OF REGULATED DEFICIT DRIP IRRIGATED PEACH
}

\section{S. M. Ismail ${ }^{1}$, A. I. Omara ${ }^{2}$, D. O. El-Ansary ${ }^{3}$ and V. Hamada ${ }^{4}$}

ABSTRACT

Egypt is one of the countries facing great challenges due to its limited water resources associated with expanding population. Therefore, new approaches for irrigation management are required to reduce water consumption and improve water use efficiency. Regulated deficit irrigation (RDI) is the strategy of reducing irrigation rates during a specific period of growth and development, with the objective of conserving water and managing plant growth while maintaining or improving yield and fruit quality. A two years old Peach trees in sandy soil under drip irrigation system were subjected to a range of irrigation deficits from pit hardening to harvest during the 2011 and 2012 seasons to evaluate the effects of deficit irrigation on peach yield. Four irrigation treatments were evaluated according to irrigation water requirements: $120 \%$ of full irrigation $\left(I_{120}\right), 100 \%$ full irrigation $\left(I_{100}\right), 80 \%$ full irrigation $\left(I_{80}\right), 60 \%$ full irrigation $\left(I_{60}\right)$.A cost-benefit analysis was performed for two and three years old peach plantation [prunuspersica] to determine profitability under regulated deficit irrigation (RDI).

The opportunity cost of water is higher than the delivery cost of water. One major point of this analysis is the dramatic differences between the delivery cost of water and its opportunity cost which is almost 10 times more than the delivery cost. It is clear that such a cost ought to be considered as the value of water.

Regression equations were developed to predict crop yield resulting from water deficit. The study recommended the model to predict crop yield and water saving. As long as the main goal is to maximize the profit as well as saving water, it could be said that the optimal profitable yield is not necessarily the maximum one, but could be less.

1 Prof. Dr. of irrigation systems, Agric. Eng., Fac. of Ag., EL-Shatby, Alex.Univ.,Egypt.

2 Dr. of irrigation systems, Agric. Eng., Fac. of Ag., EL-Shatby, Alex.Univ.,Egypt.

3 Dr. of Pomology, Precision Agric. Lab., Fac. of Ag., EL-Shatby, Alex. Univ.,Egypt.

4 Graduate Student, Agric. Eng., Fac. of Ag., EL-Shatby, Alex. Univ.,Egypt. 
Deficit irrigation technique is recommended in arid regions such as Egypt where water resources are limited.

Keywords: Drip Irrigation, Regulated deficit irrigation (RDI), Peach (prunuspersica), IWUE, production function, cost of water.

\section{INTRODUCTION}

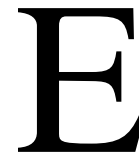

gypt stands among the largest peach producing countries in the world and occupies the 11th rank in production amongst the 17th producing countries. Egyptian peach has a relative advantage in terms of early ripening and nearness to international importing markets, in addition to the yield, fruit quality and relative low labor cost. Consequently, this creates a unique situation that favors Egypt as a potential exporter for fresh market peach fruits especially to European and Arabic Gulf countries in April and May every year due to early ripening of Egyptian peach varieties before other competition countries, therefore, the exported quantities of peach fruits have been generally increasing. For these reasons, in Egypt, the total area of peach fruits was increased from 27,000 fed. In 1982 (produced 69000 ton) to 78,494 fed in 2001 (produced 224,183 ton) to 83,703 fed in 2007 (produced 420,273 ton). Peach planting in new reclaimed lands in north of Sinai Governorate (rainfed planting) represents about $80 \%$ of the total area of peach fruits in Egypt where the average yield was about 3-4 tons/fed compared to 8-12 tons/fed ${ }^{\text {a }}$ in irrigated old lands (E. A. S. 2008 ).

In Egypt, the available water supply limits agricultural production and water saving strategies will gain importance over time as the government strives to increase the productivity of the limited water resources. Thus, Regulated deficit irrigation (RDI) is an example of irrigation management technique in the world used for reducing applied irrigation water and increase water use efficiency.

Deficit irrigation technique was introduced to find the best means to conserve irrigation water in arid lands. Regulated deficit irrigation (RDI) is a method that irrigates the entire root zone with an amount of water less

${ }^{\mathrm{a}} \mathrm{fed}=0.42$ hectare 
than the ETc (Crop- evapotranspiration) during whole or specific periods of the crop cycle.

Regulated deficit irrigation (RDI) strategies are among the methods that improve the efficiency of water use in fruit tree cultivation. Numerous studies involving these strategies indicate that certain types of fruit tree, such as pear, peach and citrus, can tolerate moderate water deficit during certain periods of the annual cycle with no important effects on production (Mitchell and Chalmers, 1982; Mitchell et al., 1984 and 1989; Ismail et al., 2015).

The best economic strategy for limited water agricultural production will often be maximizing income per unit of water available. This requires information about the crop response (yield) to water applied, ways to maximize efficiency of irrigation, the cost and value of production. Better decision can be made if the type of crop, area, and applied water can be predicted at the beginning of the cropping season. Water production function for a crop in terms of yield produced per unit of water applied, provides basic information needed to best allocate limited water supplies. Therefore, the objectives of this research are to: evaluate the effects of regulated drip irrigation deficit on peach yield and quality; develop peach water production function; and determine the point of maximum yield and the optimum applied water.

\section{MATERIALS AND METHODS}

Two seasons experiments were designed to evaluate the effect of regulated deficit irrigation (RDI) on the yield of the peach tree (prunuspersica). Irrigation treatments were conducted during fruits growing stage of peach.

\section{Site description}

The field experiment was conducted in 2011 and 2012 seasons at the experimental station of Alessra and Almiraj village, West Nubaria Rural 
Development Project (WNRDP) of the Ministry of Agriculture and Land Reclamation.

The WatchDog model 2900ET weather station located at the experimental site calculates automatically the Penman-Monteith reference evapotranspiration (PM-ETo) data. Monthly average values of air temperature (maximum and minimum), relative humidity $(\mathrm{RH})$ and reference evapotranspiration (ETo) during the growing season in the experimental station are shown in Table1.

Soil particle size analysis yielded an average value of $68.5 \%$ sand, $18 \%$ silt and $13.5 \%$ clay which classified the soil texture as sandy loam soil. The soil $\mathrm{pH}$ was 7.93 the dry soil bulk density average was $1.57 \mathrm{~g} \mathrm{~cm}^{-3}$.

\section{Experimental Plot}

\section{Plant material}

The peach trees were planted in 2009 ; tree spacing was $4.5 \times 1.5 \mathrm{~m}$ and drip irrigated by two lateral lines, with 6 emitters per tree and 4 1/h emitter discharge. Peach species (PrunusPersica L.) and Florida Prince variety was selected. Full bloom is around mid march and harvest on beginning of May. Peach fruit is described as: red skin color, yellow flesh, a medium sized, stuck nucleus, high hardness, and early maturity.

\section{Irrigation water}

The water was supplied from the left main branch number two-Sheikh Zayed canal. The water electric conductivity was $0.376 \mathrm{dS} \mathrm{m}^{-1}$ and the $\mathrm{pH}$ was 6.75 .The water used for irrigation comes from an existing surface tank on the farm to feed the drip irrigation system network through the control head which consisted of main pumping station, sand filter followed by screen filter. The main, sub main and manifold lines were made of PVC pipes in different sizes. The lateral lines were modified in the field according to the treatments distribution. A built-in emitters dripper lines were used(commercial known as GR) with a discharge of 4 $\mathrm{l} / \mathrm{h}$, at $50 \mathrm{~cm}$ spacing between emitters. 
Table 1. Monthly average values of air temperature, relative humidity, wind speed and reference evpotranspiration (ETo) in 2011, and 2012 seasons.

\begin{tabular}{|c|c|c|c|c|c|c|c|c|c|}
\hline \multirow{2}{*}{ Year } & \multirow{2}{*}{ Month } & \multicolumn{3}{|c|}{ Air Temperature c } & \multicolumn{3}{|c|}{$\%$ Humidity } & \multirow{2}{*}{\begin{tabular}{|c|}
$\begin{array}{c}\text { Wind Speed } \\
\mathrm{Km} / \mathrm{hr}\end{array}$ \\
Avg.
\end{tabular}} & \multirow{2}{*}{$\begin{array}{c}\text { Eto } \mathrm{mm} / \mathrm{day} \\
\text { Avg. }\end{array}$} \\
\hline & & Max. & Min. & Avg. & Max. & Min. & Avg. & & \\
\hline \multirow{12}{*}{2011} & January & 17.9 & 8.4 & 12.8 & 95 & 50 & 79.9 & 2.24 & 1.21 \\
\hline & February & 18 & 8.4 & 12.6 & 96.4 & 48.5 & 76 & 3.39 & 1.97 \\
\hline & March & 21.2 & 8.9 & 14.5 & 95.12 & 40 & 72.9 & 5.5 & 3.29 \\
\hline & April & 27.3 & 13.3 & 19.6 & 90.13 & 29.2 & 63.5 & 4.45 & 4.82 \\
\hline & May & 30.4 & 15.8 & 22.5 & 92.5 & 29.16 & 64.5 & 4.75 & 5.68 \\
\hline & June & 32.8 & 18.9 & 25.4 & 96.7 & 35 & 68.5 & 4.73 & 6.58 \\
\hline & July & 35.7 & 21.2 & 27.8 & 98.7 & 33 & 70.6 & 3.9 & 6.76 \\
\hline & August & 34.5 & 21.5 & 27.5 & 97 & 37 & 71.2 & 2.7 & 6.05 \\
\hline & September & 33.1 & 20 & 25.9 & 98.5 & 37.2 & 74.6 & 2 & 4.78 \\
\hline & October & 28.6 & 16.3 & 22.1 & 95.9 & 40.8 & 71.3 & 2 & 3.2 \\
\hline & November & 22.35 & 11.5 & 16.3 & 98.2 & 51.6 & 81.6 & 1.5 & 1.8 \\
\hline & December & 19.6 & 8.6 & 13.3 & 98.5 & 55.9 & 83.6 & 1.3 & 1.25 \\
\hline \multirow{2}{*}{ Year } & \multirow{2}{*}{ Month } & \multicolumn{3}{|c|}{ Air Temperature c } & \multicolumn{3}{|c|}{$\%$ Humidity } & $\begin{array}{c}\text { Wind Speed } \\
\mathrm{Km} / \mathrm{hr}\end{array}$ & Eto $\mathrm{mm} /$ day \\
\hline & & Max. & Min. & Avg. & Max. & Min. & Avg. & Avg. & Avg. \\
\hline \multirow{12}{*}{2012} & January & 18.25 & 8.49 & 12.97 & 96.23 & 51.5 & 77.96 & 2.33 & 1.32 \\
\hline & February & 18 & 8.46 & 12.68 & 96.44 & 48.5 & 76.06 & 3.93 & 2.08 \\
\hline & March & 21.29 & 8.95 & 14.58 & 95.13 & 40.03 & 72.9 & 5.59 & 3.39 \\
\hline & April & 28.75 & 12.56 & 20.19 & 92.7 & 22.07 & 60.43 & 3.14 & 4.98 \\
\hline & May & 31.71 & 16.48 & 23.68 & 91.81 & 24 & 58.9 & 4.79 & 5.76 \\
\hline & June & 34.61 & 19.82 & 26.67 & 91.93 & 27.53 & 60.17 & 5.25 & 6.61 \\
\hline & July & 35.96 & 22.31 & 28.46 & 88.39 & 16.32 & 51.81 & 2.65 & 6.52 \\
\hline & August & 36.11 & 22.11 & 28.42 & 85.19 & 8.03 & 43.42 & 3.39 & 6.32 \\
\hline & September & 32.78 & 19.73 & 25.63 & 88.31 & 9.69 & 47.46 & 5.88 & 5.72 \\
\hline & October & 30.9 & 17.38 & 23.51 & 92.9 & 31.52 & 67.26 & 2.62 & 2.92 \\
\hline & November & 26.3 & 14.64 & 20.04 & 94.84 & 40.16 & 73.32 & 2.46 & 1.65 \\
\hline & December & 21.28 & 10.12 & 15.13 & 82.52 & 34.06 & 59.81 & 4.17 & 1.56 \\
\hline
\end{tabular}




\section{Experimental Design}

Four irrigation treatments were evaluated according to irrigation water requirements: $120 \%$ of full irrigation $\left(\mathrm{I}_{120}\right), 100 \%$ full irrigation $\left(\mathrm{I}_{100}\right)$, $80 \%$ of full irrigation $\left(I_{80}\right), 60 \%$ of full irrigation $\left(I_{60}\right)$.

Irrigation control treatment $\left(\mathrm{I}_{100}=\right.$ full irrigation $)$ was scheduled according to a crop water balance technique. This treatment received water from two surface dripper lines which operated at the same time.

A randomized complete block design was established. The experimental area $(27 \times 18 \mathrm{~m})$ was divided into four treatments with three blockreplicates per treatment.

Every block consists of four plots area (plot area $=4.5 \times 9 \mathrm{~m}$ ), each plot area contains 6 trees as shown in Fig.1.

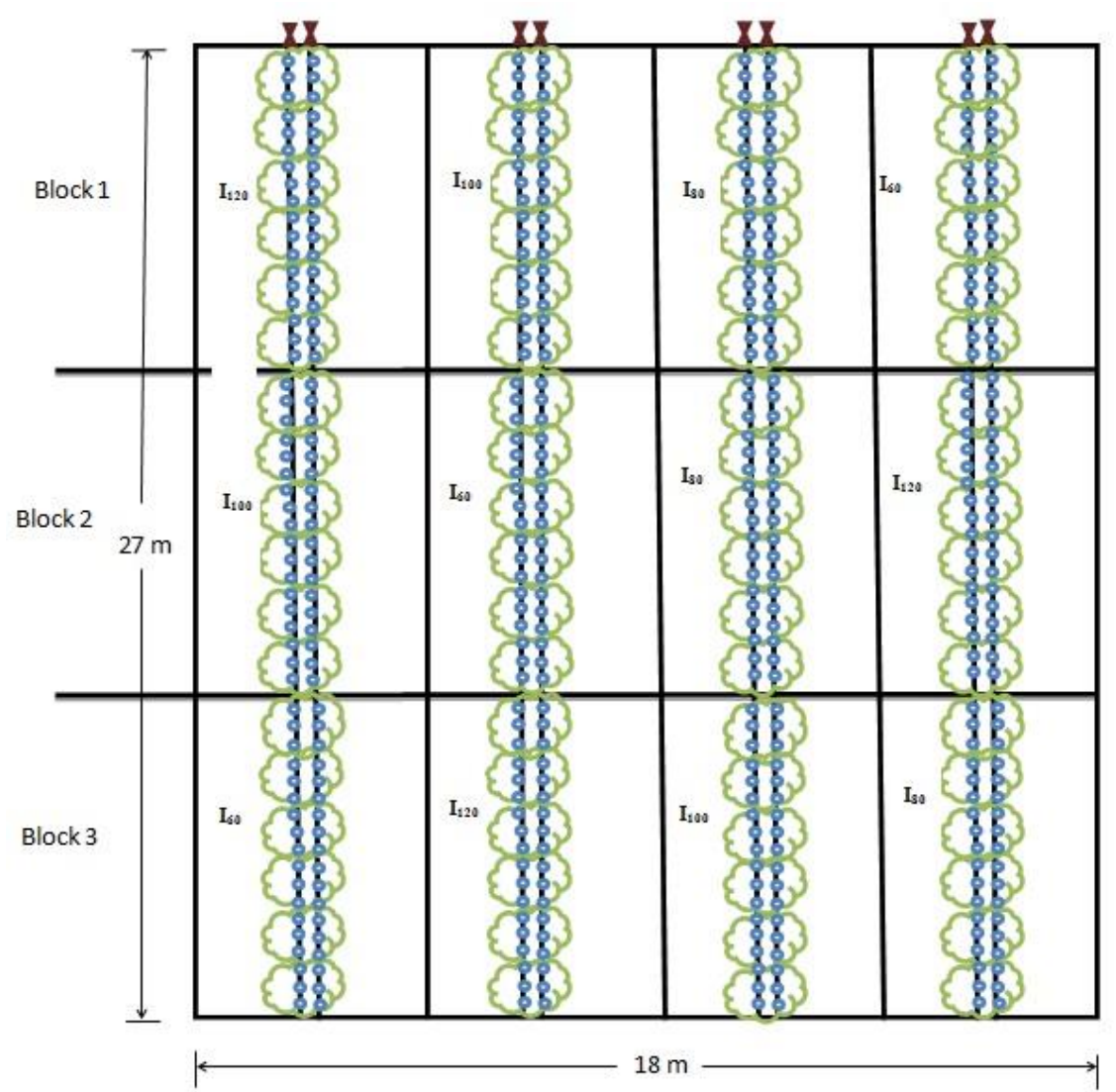

Fig 1.Irrigation treatments distribution. 


\section{Scheduling Irrigation}

Irrigation was scheduled according to a crop water balance technique (Przybyla1996 and Hess,1996). Meteorological data was used to calculate the effect of climatic factors on water consumption and the crop coefficient, which depends on the stage of crop development as shown in Eq. (1).

$$
\text { ETc }=\text { Kc. ETo }
$$

Where

ETc: Crop water consumption.

Kc: Crop coefficient which depends on the type of crop and stages of growth.

ETo: Reference evapotranspiration where calculated by the meteorological station.

Crop water consumption, the amounts of irrigation and application time were calculated based on climatic data by using the water budget approach methodology as follows:

- Estimate average daily water use rate by trees (LPD).

Where:

$$
L P D=\frac{\pi}{4} \times E T c \times D s^{2}
$$

LPD: daily rate of water use by trees (litres per tree per day).

ETc: average daily rate of water use ( $\mathrm{mm} / \mathrm{day})$.

DS: diameter of shade cast by tree at noon $(\mathrm{m})$.

- Calculate the irrigation amount.

Irrigation amount $=\frac{\text { LPD }}{\text { Application efficiency }} \times$ irrigation frequency

- Calculate the duration of water application.

Application time $=\frac{\text { Irrigation amount }}{\text { Application rate }}$

$$
=\frac{\text { Irrigation amount }}{\text { emitter } \text { discharge } \times \text { number of emitter }}
$$

\section{Soil moisture content}

To keep track of soil moisture status between irrigations, two sensors per treatment were placed to measure the tensile moisture during the growing 
season and it placed in the wetted area at a depth of 15 and $60 \mathrm{~cm}$. Watermark Soil Moisture meter was used to measure soil moisture suction in cbor $\mathrm{kPa}$ then converted to soil volumetric water content values using the $\mathrm{pF}$ curve.

\section{Water use efficiencies (IWUE)}

Irrigation water use efficiency is defined as yield of plant product per unit of crop water use.

Irrigation water use efficiency (IWUE) in the all treatments was calculated using the following Equation (Hillel andGuron, 1975):

$$
\text { IWUE }=\frac{Y}{I}
$$

IWUE: the irrigation water use efficiency $\left(\mathrm{kg} \mathrm{m}^{-3}\right)$.

Y: the yield $(\mathrm{kg})$.

$\mathrm{I}$ : the irrigation water $\left(\mathrm{m}^{3}\right)$.

\section{Production function}

Peach yield (Y) in $\mathrm{Kg} / \mathrm{fd}$ in response to water applied (I) in mm was expressed by Eq. (6).

$$
Y=a_{o}+a_{1} I+a_{2} I^{2}
$$

\section{Point of maximum yield}

The point of maximum yield $\left(\mathrm{I}_{\mathrm{m}}\right)$ can be obtained by taking the first-order partial derivatives of the yield function, setting them equal to zero, and solving simultaneously

$$
\frac{d Y}{d I}=a_{1}+2 a_{2} I
$$

When solved simultaneously,

$$
I_{m}=\frac{-a_{1}}{2 a_{2}}
$$

Substituting the above values in the yield function, Eq.(6), the maximum yield, $\mathrm{Y}_{\mathrm{m}}$, can be obtained.

At point of maximum yield, the water use efficiency, $\operatorname{IWUE}_{\mathrm{m}}(\mathrm{Kg} / \mathrm{mm})$, can be calculated as:

$$
I W U E_{m}=\frac{Y_{m}}{I_{m}}
$$




\section{Point of optimum yield}

The optimization analyses (Englsih et al., 1990; Ismail, 1993 a,b ) can be divided in to two categories; optimization when water is limited and optimization when water is not limited.

\section{Water is not limited}

The objective function can be expressed as follows;

$$
Z=P_{y} . Y-c
$$

Where:

$$
\begin{aligned}
& \mathrm{Z}=\text { total return per unit of land } \\
& \mathrm{P}_{\mathrm{y}}=\text { unit price of yield } \\
& \mathrm{C}=\text { total production costs per unit of land }
\end{aligned}
$$

The total production costs per unit of land can be expressed as:

$$
C=b_{o}+b_{1} I
$$

Where:

$$
\begin{aligned}
& b_{0}=\text { total production costs without the cost of water } \\
& b_{1}=\text { unit cost of water }
\end{aligned}
$$

The maximization of the net benefits is performed by taking the first-order partial derivatives of $Z$ and setting them equal to zero as follows:

$$
\begin{aligned}
& \frac{d Z}{d I}=p_{y} \frac{d Y}{d I}-\frac{d C}{d I}=0 \\
& \frac{d Y}{d I}=\frac{1}{p_{y}} \cdot \frac{d C}{d I}
\end{aligned}
$$

Where

$$
\frac{d C}{d I}=b_{1}
$$

Inserting Eq. (7) in to Eq. (12) and solving simultaneously, the point of optimum yield when water is not limited $\left(\mathrm{I}_{\mathrm{o}}\right)$ can be obtained as follows;

$$
I_{o}=\frac{\frac{b_{1}}{p_{y}}-a_{1}}{2 a_{2}}
$$


Where: $I_{o}$ is the optimum water per unit area when water is not limited.

\section{Water is limited}

The net farm return from all irrigated land $\left(\mathrm{Z}_{\mathrm{T}}\right)$ can be expressed as a function of the net return per unit of land $(\mathrm{Z})$ and the irrigated area $(\mathrm{A})$

$$
Z_{T}=A . Z
$$

Taking the partial derivative of Eq. (15) with respect to I, gives;

$$
\frac{d Z_{T}}{d I}=A \frac{d Z}{d I}+Z \frac{d A}{d I}
$$

When the above derivative is set equal to zero, the resulting equation is

$$
-A \cdot \frac{d Z}{d I}=Z \cdot \frac{d A}{d I}
$$

Where

Where

$$
A=\frac{I_{T}}{I}
$$

$\mathrm{I}_{\mathrm{T}}$ : total available water supply

I: water applied per unit of land

Taking the derivative of Eq. (18), yields

$$
\frac{d A}{d I}=-\frac{I_{T}}{I^{2}}
$$

Substituting Eqs. $(18,19)$ in to Eq. (17) yields

$$
I \frac{d Z}{d I}=Z
$$

Substituting Eqs.(10) for $\mathrm{Z}$ and the first-order partial derivatives of $\mathrm{Z}$, yields

$$
I\left(p_{y} \cdot \frac{d Y}{d I}-\frac{d C}{d I}\right)=p_{y} \cdot Y-C
$$

Inserting Eqs.(6, 7, 11 and 13) in to Eq. (21) and solving for I, yields

$$
I_{l}=\sqrt{\frac{p_{y} a_{o}-b_{o}}{a_{2} p_{y}}}
$$

Where $I_{1}$ is the optimum water per unit area when water is limited. 
When water is limited, Eq. (22) indicated that the total production cost $\left(b_{o}\right)$ without the cost of water is the limiting factor in determining the optimum water per unit area. However, when water is not limited, Eq. (14) indicated that the unit cost of water $\left(b_{1}\right)$ is a limiting factor in determining the optimum water per unit area.

\section{Statistical analysis}

The data for each year was analyzed (Angele, 2012)using analysis of variance (ANOVA) considering a randomized complete block design (RCBD) with three replicates. The coefficient of variation (CV) was included to compare among years. The analysis of variance was carried out by SPSS STATESTICA 20 and differences among the means were determined for significance at $\mathrm{p}<0.05$ using Newman-Keuls Post Hoc Test.

\section{RESULTS AND DISCUSSION}

\section{Applied irrigation water}

The amount of applied water in $\mathrm{mm}$ throughout all months in seasons 2011 and 2012 were presented in Figs. 2and 3. The water deficit treatments applied only during the growing stage of pit hardening to harvest (during the month of April).

Results indicated that the total amount of applied water for season 2012 were higher than that of season 2011. This is due to the progress in the growth and the increase of the trees age from 2 to 3 years by the end of the second season. The average water added during the day per tree for the control treatment was 10 to 40 liter/tree throughout the monthsexcept in December; where75 and 100 liter/treewere applied for 2 times in seasons 2011 and 2012, respectively.

Several studies indicated that Post harvest water stress decreased peach yield in the following year because there were fewer fruits per tree coinciding with the studies carried out in several Prunus sp. (Ruiz et al., 1999; Girona et al., 2003; Goldhamer et al., 2006; Naor et al., 2005). 


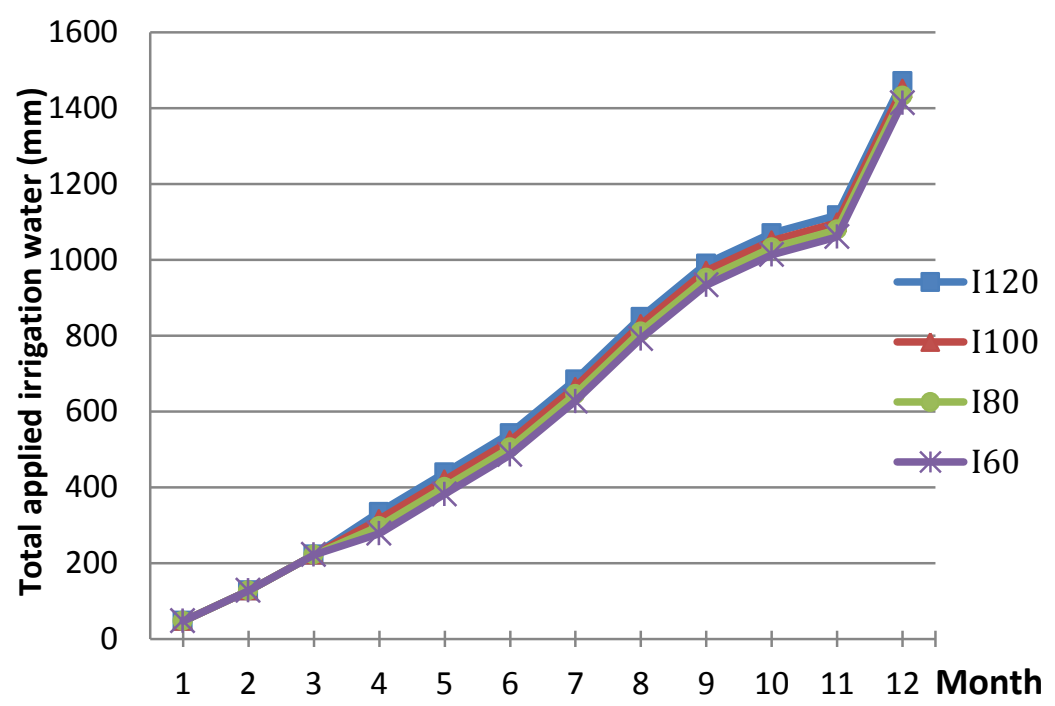

Fig. 2.The amount of applied water in $\mathrm{mm}$ throughout the 2011 season.

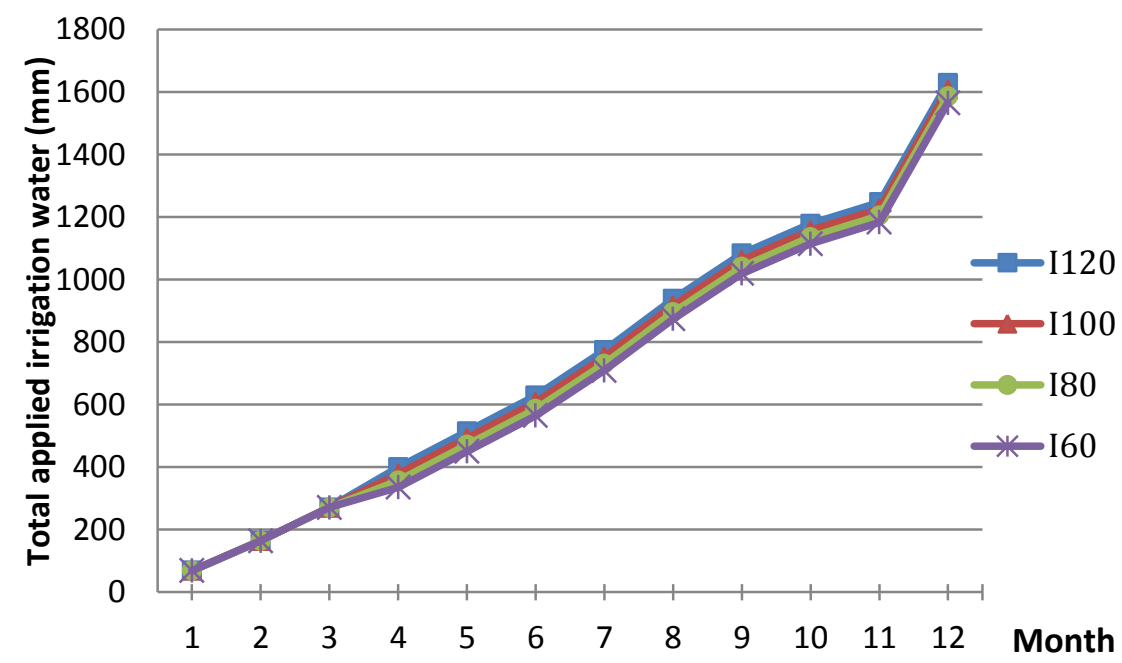

Fig. 3.The amount of applied water in mm throughout the 2012 season

\section{Water Production Function}

The obtained data showed that as the water stress increased, the yield was decreased as compared with the control $\mathrm{I}_{100}$ treatment in the two seasons 2011 and 2012 as shown in Fig. 4.

In seasons 2011 and 2012, the obtained data showed that there is significant difference between treatments as shown in Table 2 . 
The highest value of total fruit weight $(\mathrm{kg} / \mathrm{fd})$ was achieved from $\mathrm{I}_{100}$ followed by $\mathrm{I}_{120}$ and $\mathrm{I}_{80}$ and the lowest value was obtained from $\mathrm{I}_{60}$ as shown in Fig. 4.

Statistical regression analysis was conducted between total applied irrigation water in $\left(\mathrm{m}^{3} / \mathrm{fd}\right)$ as independent variable and total fruits weight $(\mathrm{kg} / \mathrm{fd})$ as dependent variable which showed a second order polynomial equation in 2012 season, as shown in Fig. 5:

$y=-0.0707 \times I^{2}+457.48 \times I-733873 \quad R^{2}=0.816$

\section{Irrigation water use efficiency (IWUE)}

The effect of irrigation treatments on irrigation water use efficiency

IWUE $(\mathrm{kg} / \mathrm{m} 3)$ in seasons 2011 and 2012 were presented in Table 2 and Fig. 6.

The obtained results indicated that there are significant differences between all treatments in the two growing seasons. The highest value of (IWUE) was achieved from $\mathrm{I}_{100}$ followed by $\mathrm{I}_{120}, \mathrm{I}_{80}$ and $\mathrm{I}_{60}$ in seasons 2011 and 2012.

Table 2. The effect of the irrigation treatments on the peach yield and IWUE $\left(\mathrm{kg} / \mathrm{m}^{3}\right)$ in seasons 2011 and 2012.

\begin{tabular}{|c|c|c|}
\hline \multicolumn{3}{|c|}{ First season (2011) } \\
Treatments & $\begin{array}{c}\text { Total fruit weight } \\
\text { kg per feddan }\end{array}$ & IWUE $\left(\mathrm{kg} / \mathrm{m}^{3}\right)$ \\
\hline $\mathrm{I}_{120}$ & $1646.32 \pm 91.17 \mathrm{~b}$ & $0.78 \pm 0.04 \mathrm{~b}$ \\
\hline $\mathrm{I}_{100}$ & $1921.19 \pm 144.38 \mathrm{~b}$ & $0.93 \pm 0.04 \mathrm{c}$ \\
\hline $\mathrm{I}_{80}$ & $1439.33 \pm 51.31 \mathrm{a}$ & $0.71 \pm 0.03 \mathrm{ab}$ \\
\hline $\mathrm{I}_{60}$ & $1353.47 \pm 33.72 \mathrm{a}$ & $0.68 \pm 0.02 \mathrm{a}$ \\
\hline \multicolumn{3}{|c|}{ Second season $(2012)$} \\
\hline Parameters & $\begin{array}{c}\text { Total fruit weight } \\
\text { kg per feddan }\end{array}$ & IWUE $\left(\mathrm{kg} / \mathrm{m}^{3}\right)$ \\
\hline $\mathrm{I}_{120}$ & $5910.95 \pm 406.25 \mathrm{~b}$ & $1.92 \pm 0.04 \mathrm{~b}$ \\
\hline $\mathrm{I}_{100}$ & $6133.51 \pm 51.09 \mathrm{~b}$ & $1.97 \pm 0.02 \mathrm{~b}$ \\
\hline $\mathrm{I}_{80}$ & $5156.24 \pm 475.94 \mathrm{a}$ & $1.68 \pm 0.15 \mathrm{a}$ \\
\hline $\mathrm{I}_{60}$ & $4728.28 \pm 51.52 \mathrm{a}$ & $1.56 \pm 0.02 \mathrm{a}$ \\
\hline
\end{tabular}




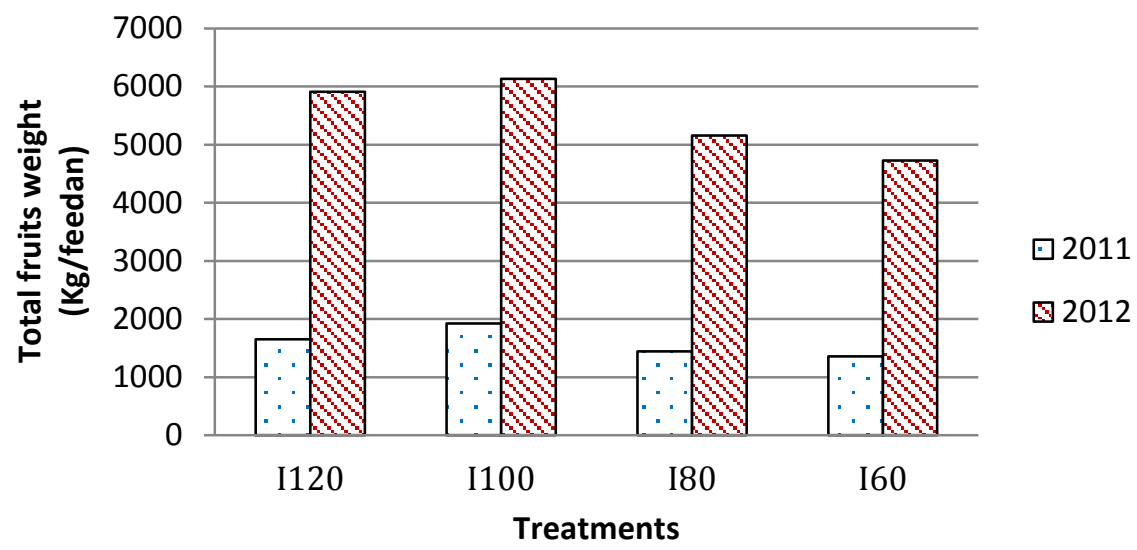

Fig. 4.The effect of the irrigation treatments on total fruits weight (kg/feddan) in seasons 2011 and 2012.



Fig. 5. Relationship between total fruit weight(kg / feddan) and total applied irrigation water $\left(\mathrm{m}^{3} /\right.$ feddan $)$ in season 2012.

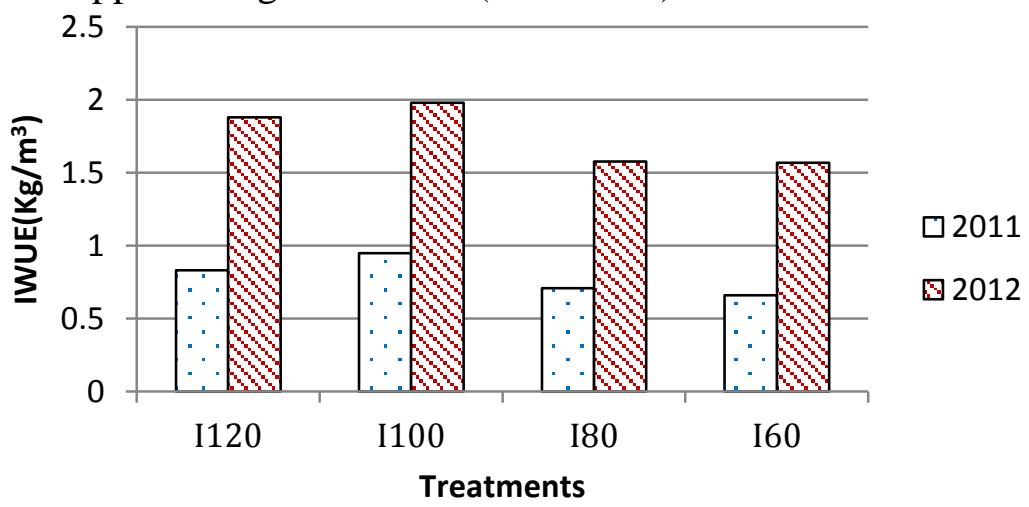

Fig. 6.The effect of the irrigation treatments on IWUE $\left(\mathrm{kg} / \mathrm{m}^{3}\right)$ in seasons 2011 and 2012. 


\section{Cost-Benefit Analysis}

Cost-benefit analysis provides a rational and systematic framework for assessing alternative management and policy options. It entails identification and economic valuation of all positive and negative effects of alternative options.

\section{Total annual costs}

Operating costs are the short run cash expenses that will vary with the level of output. Fixed costs are the overhead costs that may not vary with output. The fixed costs include depreciation, interest, and repairs. A land and overhead charges are also included as fixed costs.

Table 3 illustrated the fixed annual cost of early peach crop and Table 4 showed the fixed and operation costs in seasons 2011 and 2012.The fixed costs included digging land, rent of the land, irrigation network, planting and motor sprayer. Operating costs consists of winter service, pest control, labor, fertilizers and irrigation cost.

Capital Recovery Factor:The capital recovery factor(CRF)is calculated from the following equation:

$$
\mathrm{CRF}=\left(\mathrm{i} \times(1+\mathrm{i})^{\mathrm{n}}\right) /\left((1+\mathrm{i})^{\mathrm{n}}-1\right)
$$

Where $\mathrm{I}$ and $\mathrm{n}$ are the real interest rate and the project lifetime assumed equal to $10 \%$ and 15 years, respectively.

Table 3.Fixed annual cost of early peach crop.

\begin{tabular}{|c|c|c|c|c|}
\hline Item & $\begin{array}{c}\text { Initial cost } \\
\text { (EGP) }\end{array}$ & $\begin{array}{l}\text { Years of } \\
\text { life, }(\mathbf{N})\end{array}$ & $\begin{array}{c}\text { Capital Recovery } \\
\text { Factor, (CRF) }\end{array}$ & $\begin{array}{l}\text { Annual cost }(\mathrm{EGP}) \\
=\mathrm{CRF} * \text { initial cost }\end{array}$ \\
\hline Auger & 1200 & 15 & 0.13147 & 157.77 \\
\hline Land rental & 7000 & 1 & 1 & 7000 \\
\hline $\begin{array}{c}\text { Irrigation } \\
\text { network }\end{array}$ & 2500 & 15 & 0.13147 & 328.68 \\
\hline $\begin{array}{l}\text { Trees \& } \\
\text { planting }\end{array}$ & 7464 & 15 & 0.13147 & 981.32 \\
\hline Miscellaneous & 1500 & 15 & 0.13147 & 197.21 \\
\hline Sprayer & 1000 & 15 & 0.13147 & 131.47 \\
\hline \multicolumn{4}{|c|}{ Total fixed annual cost EGP/fd } & 8796.46 \\
\hline
\end{tabular}


Table 4. Operating costs for full irrigation in seasons 2011 and 2012.

\begin{tabular}{|c|c|c|}
\hline Item & $\begin{array}{c}\text { First season } \\
2011\end{array}$ & $\begin{array}{c}\text { Second season } \\
2012\end{array}$ \\
\hline Winter service & 1555.56 & 1555.56 \\
\hline Pest control & 1011.56 & 1115.48 \\
\hline Labour & 500 & 750 \\
\hline Fertilizers & 2825.38 & 3033.43 \\
\hline Irrigation & 255.97 & 387.31 \\
\hline Operating costs & 6148.47 & 6841.77 \\
\hline Total annual costs & 14944.9 & 15638.2 \\
\hline
\end{tabular}

Total income: The total income can be calculated as follows;

Total income $(\mathrm{EGP})=$ Yield $(\mathrm{kg} /$ feddan $) *$ Value of crop per unit $(\mathrm{EGP})$

Table 5.Total income (EGP/fd) for each treatment in two seasons 2011 and 2012.

\begin{tabular}{|c|c|c|c|c|c|c|}
\hline & \multicolumn{3}{|c|}{ First season 2011 } & \multicolumn{3}{c|}{ Second season 2012} \\
\hline $\begin{array}{c}\text { Treat- } \\
\text { ment }\end{array}$ & $\begin{array}{c}\text { Yield } \\
(\mathrm{kg} / \mathrm{fd})\end{array}$ & $\begin{array}{c}\text { Value of } \\
\text { crop per } \\
\text { unit } \\
(\mathrm{EGP} / \mathrm{kg})\end{array}$ & $\begin{array}{c}\text { Total } \\
\text { income } \\
(\mathrm{EGP} / \mathrm{fd})\end{array}$ & $\begin{array}{c}\text { Yield } \\
(\mathrm{kg} / \mathrm{fd})\end{array}$ & $\begin{array}{c}\text { Value } \\
\text { of crop } \\
\text { per unit } \\
(\mathrm{EGP})\end{array}$ & $\begin{array}{c}\text { Total } \\
\text { income } \\
(\mathrm{EGP} / \mathrm{fd})\end{array}$ \\
\hline $\mathbf{I}_{\mathbf{1 2 0}}$ & $\mathbf{1 6 4 6}$ & $\mathbf{3}$ & $\mathbf{4 9 3 8}$ & $\mathbf{5 9 1 0 . 9 5 6}$ & $\mathbf{4}$ & $\mathbf{2 3 6 4 3 . 8 2}$ \\
\hline $\mathbf{I}_{\mathbf{1 0 0}}$ & $\mathbf{1 9 2 1 . 1 9}$ & $\mathbf{3}$ & $\mathbf{5 7 6 3 . 5}$ & $\mathbf{6 1 3 3 . 5 1 2}$ & $\mathbf{4}$ & $\mathbf{2 4 5 3 4 . 0 4}$ \\
\hline $\mathbf{I}_{\mathbf{8 0}}$ & $\mathbf{1 4 3 9}$ & $\mathbf{3}$ & $\mathbf{4 3 1 7}$ & $\mathbf{5 1 5 6 . 2 4 4}$ & $\mathbf{4}$ & $\mathbf{2 0 6 2 4 . 9 8}$ \\
\hline $\mathbf{I}_{\mathbf{6 0}}$ & $\mathbf{1 3 5 3}$ & $\mathbf{3}$ & $\mathbf{4 0 5 9}$ & $\mathbf{4 7 2 8 . 2 8 1}$ & $\mathbf{4}$ & $\mathbf{1 8 9 1 3 . 1 2}$ \\
\hline
\end{tabular}

The Net Return: Net return is the gross sales minus production costs. It varies with changes in yield, price, and production costs and calculated as follows;

The Net Return=Total income (EGP/feddan) - Total annual cost (EGP/feddan) 
Table 6. The Net Return (EGP) for each treatment in two seasons 2011 and 2012.

\begin{tabular}{|c|c|c|}
\hline \multicolumn{3}{|c|}{ The Net Return (EGP) } \\
\hline Treatment & First season 2011 & Second season 2012 \\
\hline $\mathrm{I}_{120}$ & -10006.9 & 8005.62 \\
\hline $\mathrm{I}_{100}$ & -9181.4 & 8895.82 \\
\hline $\mathrm{I}_{80}$ & -10627.9 & 4986.78 \\
\hline $\mathrm{I}_{60}$ & -10885.9 & 3274.92 \\
\hline
\end{tabular}

The second year of growth is considered as a developing year in a commercial peach orchard. With proper management, some production is often harvested in the second year, so the net return (EGP) in season 2011 was a negative value. The grower would have to forego a self sustaining income stream for the first two years. The cash flow analysis indicates that a positive net annual difference between costs and receipts is realized during the third year.

A positive accumulated net difference could occurs during the fifth year. Of course, with variations in production costs, yields, and prices, the cash flow would change and the planted acreage would be the factor that would ultimately determine the returns on investment (Timothy, 1982).

\section{Delivery Cost of Water}

Total annual cost of water $=$ annual irrigation fixed cost + annual operating cost

Annual operating costs of irrigation consists of irrigation costs only, this means excluding other costs like fertilizers, winter service, pest control and labour.

Total amount of water pumped annually $\left(\mathrm{m}^{3} /\right.$ year $)=$ number of hours operation per year×pump discharge $\left(\mathrm{m}^{3} / \mathrm{hr}\right)$

First season 2011

Number of hours operation per year $=343$ hours

Pump discharge $=6 \mathrm{~m}^{3} / \mathrm{hr}$

Total amount of water pumped $=2058 \mathrm{~m}^{3} /$ year

Second season 2012

Number of hours operation per year $=519$ hours

Pump discharge $=6 \mathrm{~m}^{3} / \mathrm{hr}$

Total amount of water pumped $=3114 \mathrm{~m}^{3} /$ year 
Cost of pumping water $(\mathrm{EGP})=$ Total annual cost $(\mathrm{EGP} / \mathrm{year}) /$ Total amount of water pumped annually $\left(\mathrm{m}^{3} /\right.$ year $)$

First season 2011

Cost of pumping water $=0.284 \mathrm{EGP} / \mathrm{m}^{3}$

Second season 2012

Cost of pumping water $=0.229 \mathrm{EGP} / \mathrm{m}^{3}$

The cost of pumping water is equal to $0.28 \mathrm{EGP} / \mathrm{m}^{3}$ in season 2011 , but in season 2012 the value of pumping cost of water for $\mathrm{I}_{100}$ treatment was 0.229 EGP. The cost of pumping water in first season was higher than second season because the total annual cost and the total amount of water pumped annually in season 2012 were higher than second season.

\section{Opportunity Cost of water}

The value of water is much more than the delivery cost of water. Economic theory states that the opportunity cost is the best measure of value. In an arid land, this is much greater than in humid regions. One approximation of this opportunity cost of water would be to consider the profit available where another feddan of land brought under irrigation using the water saved from applying less. Therefore, shadow price of water has to be estimated in order to estimate the opportunity cost of water.

The net benefit function can be written as:

$\mathrm{NB}=\mathrm{P} . \mathrm{Y}-\mathrm{C}_{\mathrm{d}} \cdot \mathrm{X}-\mathrm{C}_{\mathrm{t}}$

Where:

NB: net benefit (EGP/fd)

P: market price of the crop (EGP/kg)

$\mathrm{Y}$ : crop yield in $(\mathrm{kg} / \mathrm{fd})$

$\mathrm{C}_{\mathrm{d}}$ : delivery cost per unit of water in $(\mathrm{EGP} / \mathrm{fd})$

$\mathrm{X}$ : the amount of water in $\left(\mathrm{m}^{3} / \mathrm{fd}\right)$

Ct: all other cost in (EGP/fd)

Opportunity Cost of water $\left(\mathrm{EGP} / \mathrm{m}^{3}\right)=$ Net benefit $(\mathrm{EGP} /$ feddan $) /$ Total amount of water pumped annually $\left(\mathrm{m}^{3} /\right.$ feddan)

The net benefit and the opportunity cost of water for $\mathrm{I}_{100}$ treatment was 8895.82 EGP/fd, and 2.857 EGP/m ${ }^{3}$, respectively. 
It can be seen that the opportunity cost of water is higher than the delivery cost of water. One major point of this analysis is the dramatic differences between the delivery cost of water and its opportunity cost which is almost 10 times more than the delivery cost. Only farmers with more land might possibly be influenced by this fact however it is clear that such a cost ought to be considered as the value of water.

\section{Point of maximum yield}

To obtain the point of maximum yield, the first derivative of the water production function, Eq (23), is set equal to zero as follows:

$$
\begin{aligned}
& \frac{d Y}{d I}=-2 \times 0.0707 \times \mathrm{I}+457.48=0 \\
& \mathrm{I}_{\max }=3235.361 \mathrm{~m}^{3}
\end{aligned}
$$

Solving Eq. (23), maximum yield equal:

$\mathrm{Y}_{\text {max }}=-0.0707 \times(3235.361)^{2}+457.48 \times(3235.361)-733873$

$\mathrm{Y}_{\text {max }}=6183.402 \mathrm{~kg} / \mathrm{fd}$

At point of maximum yield the water use efficiency, IWUE $\left(\mathrm{Kg} / \mathrm{m}^{3}\right)$, can be calculated as:

$$
\begin{aligned}
\operatorname{IWUE}_{\mathrm{M}} & =\frac{\mathrm{Y}_{\mathrm{M}}}{I_{M}} \\
\operatorname{IWUE}_{\mathrm{M}} & =\frac{6183.402}{3235.361}=1.9111 \mathrm{~kg} / \mathrm{m}^{3}
\end{aligned}
$$

\section{Point of optimum yield}

Recently, emphasis has been placed on the concept of water productivity (WP), defined here either as the yield or net income per unit of water used (Kijneet., al 2003).

Water is not limited: To obtain the point of optimum yield, the first derivative of the water response function, Eqs. (10) and (11), are set equal to zero and inserting Eq. (7) in to Eq. (12) and solving simultaneously, the point of optimum yield when water is not limited $\left(\mathrm{I}_{\mathrm{o}}\right)$ can be obtained as follows;

$\mathrm{I}_{\mathrm{o}}=\frac{\mathrm{b}_{1} / \mathrm{p}_{\mathrm{y}}-a_{1}}{2 a_{2}}$ 
$\mathrm{b}_{1}$ : delivery cost per unit of water

$\mathrm{p}_{\mathrm{y}}$ : unit price of yield

$\mathrm{I}_{0}=\frac{(0.229 / 4)-457.48}{2(-0.0707)}=3234.96 \mathrm{~m}^{3}$

Solving Eq. (23), optimum yield equal:

$Y_{0}=-0.0707 \times(3234.96)^{2}+457.48 \times(3234.96)-733873$

$\mathrm{Y}_{\mathrm{o}}=6183.39 \mathrm{~kg}$

At point of optimum yield the water use efficiency, IWUE $\left(\mathrm{Kg} / \mathrm{m}^{3}\right)$, can be calculated as

IWUE $_{0}=6183.3 / 3234.99=1.911 \mathrm{~kg} / \mathrm{m}^{3}$

Water is limited: The point of optimum yield when water is limited $\left(\mathrm{I}_{\mathrm{L}}\right)$ can be obtained by Eq. (22) by taking the partial derivative of Eq. (15) with respect to I , then set equal to zero and taking the derivative of Eq. (18),followed by substituting Eqs. $(18,19)$ into Eq. (17)and inserting Eqs. $\left(6,7,11\right.$ and 19) into Eq. (21) and solving for $\left(\mathrm{I}_{\mathrm{L}}\right)$

$\mathrm{I}_{\mathrm{L}}=\sqrt{((P y \times a o)-b o) /\left(a_{2} \times P y\right)}$

$\mathrm{I}_{\mathrm{L}}=\sqrt{((4 \times-733873)-14682.5) /(-0.0707 \times 4)}$

$\mathrm{I}_{\mathrm{L}}=3229.863 \mathrm{~m}^{3}$

Substituting the value of $I_{L}$ in Eq. (23), the optimum yield can be obtained as follows;

$Y_{L}=-0.0707 \times(3229.863)^{2}+457.48 \times(3229.86)-733873$

$\mathrm{Y}_{\mathrm{L}}=6181.265 \mathrm{~kg}$

At point of optimum yield the water use efficiency, IWUE $\left(\mathrm{Kg} / \mathrm{m}^{3}\right)$, can be calculated as:

$\operatorname{IWUE}_{\mathrm{L}}=6181.265 / 3229.863=1.9137 \mathrm{~kg} / \mathrm{m}^{3}$

It can be seen that the optimum point is slightly less than the point of maximum yield. Maximizing income per unit of water available is the best economic strategy for water limited agricultural production. This 
requires information about the crop response to water applied, ways to maximize efficiency of irrigation, the cost and value of production. Better decision can be made if the applied water can be predicted at the beginning of the growing season. Water production function for a crop in terms of yield produced per unit of water applied, provides basic information needed to best allocate limited water supplies. As long as the main goal is to maximize the profit as well as saving water, it could be said that the maximum yield is not necessarily the optimal one, but could be less.

\section{SUMMARY}

Regulated deficit irrigation (RDI) is the strategy of reducing irrigation rates during a specific period of growth and development, with the objective of conserving water and managing plant growth while maintaining or improving yield and fruit quality. A two years old Peach tree in sandy soil under drip irrigation system were subjected to a range of irrigation deficits from pit hardening to harvest during the 2011 and 2012 seasons to evaluate the effects of deficit irrigation on peach yield. Regression equations were developed to predict crop yield resulting from water deficit. A cost-benefit analysis was performed for two and three years old peach plantation [prunuspersica] to determine profitability under regulated deficit irrigation (RDI). The cost of pumping water was equal to $0.229 \mathrm{EGP} / \mathrm{m}^{3}$ in 2012 season, while, the opportunity cost of water was $2.857 \mathrm{EGP} / \mathrm{m}^{3}$. It can be seen that the opportunity cost of water is almost 12 times more than the delivery cost. It is clear that such a cost ought to be considered as the value of water.

The point of maximum yield was $6183.402 \mathrm{~kg} / \mathrm{fd}$ at applied water of $3235.361 \mathrm{~m}^{3} / \mathrm{fd}$. At point of maximum yield, the water use efficiency was $1.91 \mathrm{Kg} / \mathrm{m}^{3}$.

The point of optimum yield when water is not limited was $6183.39 \mathrm{~kg} / \mathrm{fd}$ at applied water of $3234.96 \mathrm{~m}^{3} / \mathrm{fd}$. However, at point of optimum yield, the water use efficiency was $1.911 \mathrm{Kg} / \mathrm{m}^{3}$.

\section{REFERENCES}

Angele, G. (2012). SPSS Statistics 20. EineEinführung, Otto-FriedrichUniversität. 
E. A. S. 2008. Economic Affairs Sector, Ministry of Agric. and Land reclamation, A.R.E.

Englsih, M.J., Music, J.T., Murty, V.V.N., 1990. Deficit irrigation. In: Hoffman, G.J., Howell, T.A., Solomon, K.H. (Eds.), Management of Farm Irrigation Systems. ASAE Monograph, Michigan, pp. 631663.

Girona J, Mata M, Arbone's A, Alegre S, Rufat J, Marsal J (2003) Peach tree response to single and combined regulated deficit irrigation regimes under shallow soils. J Am SocHorticSci 128:432-440.

Goldhamer DA, Viveros M, Salinas M (2006) Regulated deficit irrigation in almonds: effects of variations in applied water and stress timing on yield and yield components. IrrigSci 24:101-114.

Hess, A. 1996.A microcomputer scheduling program for supplementary irrigation.In:Irrigation Scheduling: From Theory to Practice, Proceedings ICID/FAO Workshop, Sept. 1995, Rome. Water Report No. 8, FAO, Rome.

Hillel D and Guron Y (1975). Relation between evapotranspiration rate and maize yield. Water Res., 9: 743-748.

Ismail, S.M. 1993 a. (1413 A.H.). Optimal irrigation and wheat yield response to applied water. J. King Saud Univ., Vol.5, Agric. Sci. (1),pp.41-56.

Ismail, S.M. 1993 b. Sprinkler-irrigated wheat production function and mathematical optimization. Alex. J. Agric. Res. 38(3):51-69.

Ismail, S.M., T.K. Zin El-abedin, D. El-Ansary, and A. Abdel-Al, 2015.Modification of FAO Crop Model to Simulate Yield Response to Water for Peach Trees.Misr J. Ag. Eng., 32(1): 145 - 172.

Kijne JW, Barker R, Molden DJ. 2003. Water productivity in agriculture: limits and opportunities for improvement. Wallingford,UK: CABI, IWMI.

Mitchell, P.D. \& Chalmers, D.J. 1982.The effect of reduced water supply on peach tree growth and yields. Journal of the American Society for Horticultural Science 107:853-856. 
Mitchell, P.D., van den Ende, B., Jerie, P.H. and Chalmers, D.J. 1989. Response of "Bartlett" pear to witholding irrigation, regulated deficit irrigation, and tree spacing. Journal of the American Society of Horticultural Science 114: 15-19.

Mitchell, P.D.., Jerie P.H., Chalmers, D.J. 1984. Effects of regulated water deficits on pear tree growth, flowering,fruit growth and yield. J Am SocHorticSci 109,604-606.

Naor A, Stern R, Peres M, Greenblat Y, Gal Y, Flaishman MA (2005) Timing and severity of postharvest water stress affect followingyear productivity and fruit quality of field-grown 'Snow Queen' nectarine. J Am SocHorticSci 130:806-812.

Przybyla, C. 1996. Irrigation scheduling in large-scale sprinkler irrigation in the Wielkopolska region (Poland). In: Irrigation Scheduling: From Theory to Practice, Proceedings ICID/FAO Workshop, Sept. 1995, Rome. Water Report No. 8, FAO, Rome.

Ruiz-Sa'nchez MC, Egea J, Galego R, Torrecillas A (1999) Floral biology of $\mathrm{Bu}$ 'lida apricot trees subjected to postharvest drought stress. Ann ApplBiol 135:523-528.

Timothy D. Hewitt . (1982). AN ENTERPRISE COST ANALYSIS OF PEACH PRODUCTION IN FLORIDA1. Proc. Fla. Slate Hort. Soc, 95:98-101.

\section{الملخص العربي}

دالة إنتاج الخوخ وقيمها الرياضية المثلي للتقص المجدول في الري بالتنقيط

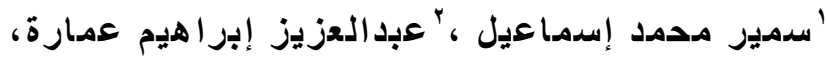



يعتبر النقص المجدول للري أحد إستر اتيجيات ترشيد المياه حيث يتم إضافة معدلات الري بأقل

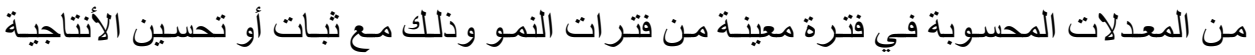
و الجودة. وفي هذا البحث تم تطبيق هذة الطريقة علي أشجار الخوخ في مرحلة تصلب نمو الثمرة



1 أستاذ هندسة نظم الري، قسم الهندسة الزراعية والنظم الحيوية، كلية الزراعة، الثاطبى، جامعة الإسكندرية.

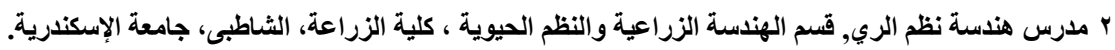

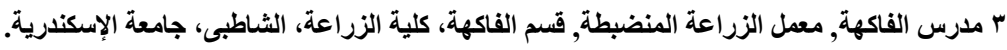

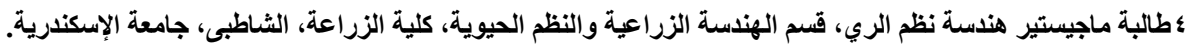




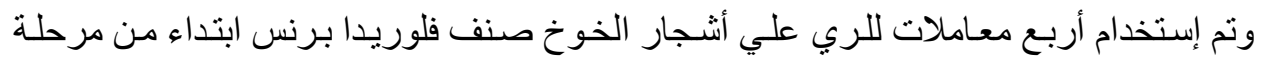

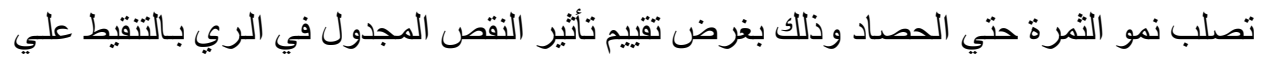



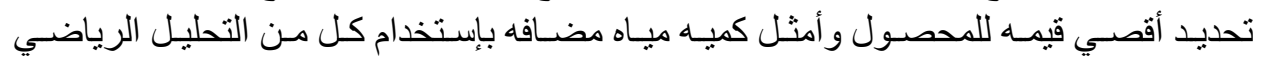

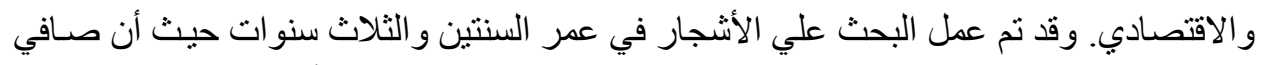

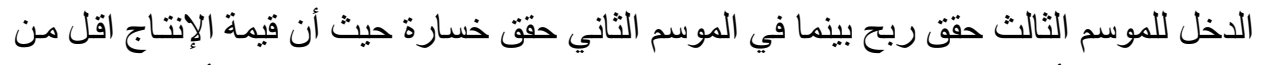

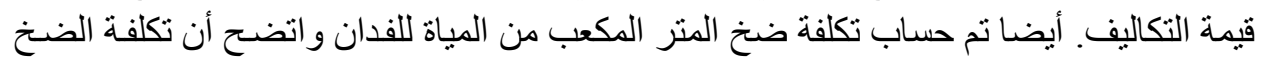



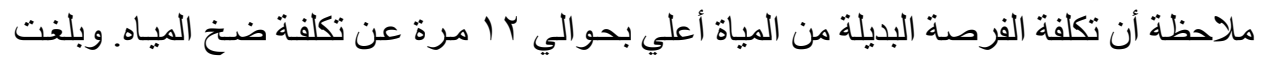

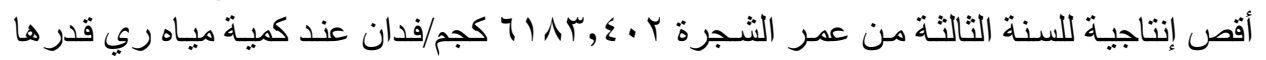

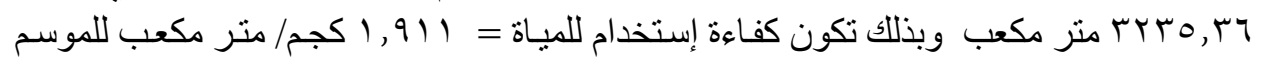
الثاني.

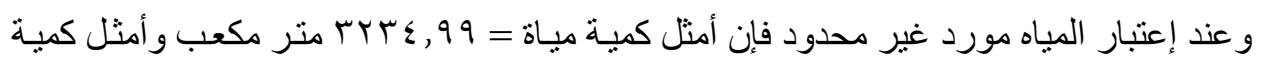


مكعب للموسم الثاني.

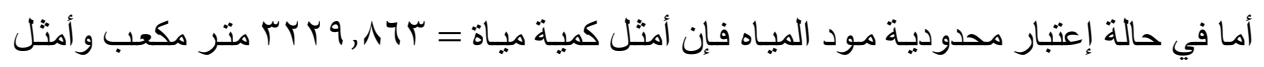

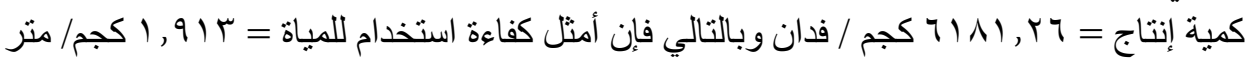
مكعب للموسم الثناني.

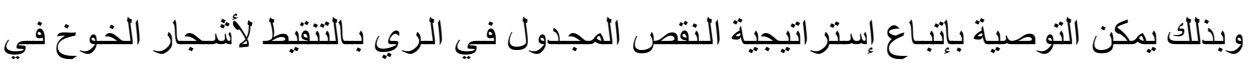


أيضا. 